\title{
EPISTEMOLOGI GERAKAN LIBERALIS, FUNDAMENTALIS, DAN MODERAT ISLAM DI ERA MODERN
}

\author{
Alamul Huda \\ Fakultas Syariah UIN MALIKI Malang \\ Email:alamulhuda09@gmail.com
}

\begin{abstract}
Abstrak
The episthemology of Islamic fundamentalism and liberalism movement in modern era has significant meaning. These two movements influence significantly on Muslim's value and behavior as well as their religiosity. As it has been known that each movement has its own main principle. On the onehand fundamentalism empahasizes qur'an and sunnah movement with its litaralist movement, muslim thinkers try to reinterprete those islamic sources islamic values with modern thinking as the requirement to face and to solve contemporary problems, on the other. Therefore, it should be acknowledged that muslim restore religious concept and start to reanalyze tafsir and sunnah based on human situation, social law, gender justice. Finally, it is undisputable that each religious movement has its own character.

Epistemologi dari gerakan Islam fundamentalis dan Islam liberalis di era modern memiliki arti penting. Dua gerakan ini memberikan pengaruh signifikan terhadap nilai dan perilaku serta paradigma keberagamaan umat Islam. Sebagaimana di ketahui, bahwa dari masing-masing gerakan yang ada memiliki prisip utama, sebagamana dalam Gerakan Islam Fundamentalis menyeru untuk kembali pada al-Qur'an dan Sunnah dengan pendekatan literal tekstual pada tafsir ayat-ayatnya, di sisi yang lain, para pemikir Islam menyeru untuk melakukan pemaknaan ulang nilai-nilai keislaman dengan menggunakan pemikiran modern sebagai syarat untuk menghadapi dan memecahkan persoalan-persoalan kemanusiaan terkini, oleh sebab itu, nampak bahwa masyarakat muslim seharusnya merestorasi konsep keagamaan di semua bidang dan memulai analisis ulang terhadap tafsir dan as-Sunnah berdasar situasi kemanusiaan, hukum social dan keadilan gender, yang pada akhirnya, tidak dapat di pungkiri bahwa pada masingmasing gerakan keagamaan memiliki karakter tersendiri.
\end{abstract}

Kata kunci: epistemologi, fundamentalis dan liberalis

Manusiaberdasarkanpadakeberadaandan penciptaannya merupakan makhluk sosial yang perilaku, tindak tanduk dan aktivitas pribadi ataupun sosialnya terikat pada nilainilai atau konsensus bersama dalam satu komunitas sosial masyarakat. Dasar-dasar utama dari nilai atau konsesus tersebut mengikat serta membatasi "kebebasan" manusia satu dengan yang lainnya, baik secara langsung lewat aturan yang tersurat ataupun secara tidak langsung yang biasanya berdasar pada kesepakatan bersama dan tidak tertulis serta bersifat "kondisional dan situasional", hukum yang pertama ini yang lazim di nisbatkan pada hukum adat, sedangkan hukum lainnya, dinyatakan dalam hukum tertulis yang mengakibatkan dikenakannya sanksi hukuman tertentu bagi siapa saja yang melanggarnya, baik menggunakan sistem hukum konvensional ataupun yang 
mengadopsi tipologi hukum Islam (baca; Syariah).

Hukum terklasifikasi menjadi hukum adat, konvensional dan hukum Islam, yang kesemuanya berpengaruh pada kategori jenis kejahatan dan jenis hukuman (uqubat) bagi sang pelaku, dengan standarisasi yang bergantung pada ruang dan waktu juga daerah dimana hukum itu hadir. Di ranah lain ada aturan yang tidak tertulis namun hanya tersurat yang erat dengan tradisi dan budaya dari satu daerah yang juga menuntut untuk di patuhi. Adalah lazim dalam kehidupan bila terdapat pendukung dan penentang atas pemberlakuan hukum dan aturan tersebut, tidak terkecuali hukum Tuhan yang tersurat dalam tata aturan agama, yang tertuang nyata dalam al-Qur'an dan sunnah nabawiyah serta ijtihad ulama.

Ruang dan waktu telah membentuk gerakan pembaharuan (tajdid) bagaimana kaum muslimin keluar dari kotak-kotak taklid dan mazhab, munculnya kaum liberal yang menyeru pada pembacaan ulang hal-hal yang sudah qath'iy dan tsubut dalam agama dengan metode baru, dan kaum yang memilih sikap tengah dalam semangat beragama (tadayyun). ijtihad telah dan selalu di lakukan guna mengeksplorasi kepatutan dalam penerapan hukum Islam beserta kaidahkaidahnya dalam menberi solusi terhadap masalah-masalah agama yang muncul di tengah masyarakat yang diwakili oleh mereka yang menginginkan adanya tajdid, lalu bahasan tentang kepantasan beragama dengan akulturasi antara agama dengan tradisi, adat dan budaya lokal yang di lakukan oleh mereka yang berpaham moderat, hingga segolongan mereka yang meletakkan konsep bid'ah (melakukan hal-hal yang baru dalam beragama) adalah sikap rendah dan harus dibuang karena ia dianggap sebagai benalu aqidah tentang ke-Esa-an Tuhan yang dilakukan oleh wahabi dan salafi.

\section{Fundamentalisme, Liberalisme dan Moderasi dalam Islam}

Dalam sejarah kaum muslimin, setelah merapuhnya dinasti Utsmaniyah di Tur- ki, yang akhirnya runtuh pada era kepemimpinan Mustafa Kamal at-Tataruk di sekitar pertengahan tahun 1924 M, lalu muncul periode kebangkitan kembali umat Islam setelah merebaknya kesadaran akan kemunduran dan kelemahan ummat Islam yang semakin parah. Umat Islam mulai menyadari bahwa peradaban dunia barat telah jauh lebih maju dan melangkah lebih jauh, yang hal tersebut akan menjadi ancaman tersendiri bagi Dunia Islam. Pada periode inilah, terdapat transisi pergeseran nilai, gagasan dan gerakan (movement) di dalamnya, dan - tentunya - memiliki makna signifikan berkat keinginan kuat dan semangat revivalisme yang dimotori oleh Jamaluddin al-Afghani (1839M-1897M) dengan Pan Islamisme, Muhammad Rashid Ridha (1865M-1935M), Muhammad al-Sanusi (1791M-1859M) di Libya dan Maroko dan Muhammad Abduh (1849M-1906M). ${ }^{1}$ Kesadaran umat Islam berawal dari kejatuhan Mesir ke tangan Napoleon Bonaparte $^{2}$ pada tahun $1798 \mathrm{M}$, sehingga menggugah kaum muslimin untuk beranjak dari stagnasi pemikiran, ijtihad, taklid buta dan tidak terkotak-kotak pada madzab dan politik aliran serta lebih mengutamakan kembali pada ajaran murni al-Qur'an dan Sunnah Rasulullah Saw. Para ulama dan pemikir pembaharu dalam Islam, melihat bahwa perlu adanya pembangunan kembali pemikiran dalam Islam termasuk dalam Fiqih. Jika kita membaca sejarah, sebenarnya usaha ini telah diawali sejak peralihan abad ke tiga belas dan empat belas oleh seorang ulama' besar syaikh Ibn Taymiyah $(661 \mathrm{H}-728 \mathrm{H})$ yang dikenal sebagi ulama' penentang kedzaliman penguasa dan tidak kenal lelah memperjuangkan penerapan Islam secara menyeluruh dalam Negara Islam, di samping

\footnotetext{
${ }^{1}$ Alaiddin Koto. . Ilmu figih dan Ushul Figh. Jakarta: PT. Raja Grafindo Persada. 2006..., h. 23- 24.

Secara historis, modernisasi pendidikan di Mesir berawal dari pengenalan kemajuan ilmu pengetahuan dan teknologi Napoleon Bonaparte pada saat penaklukan Mesir. Kemajuan ilmu pengetahuan dan tehnologi yang dicapai oleh Napoleon Bonaparte yang berkebangsaan Perancis ini, memberikan inspirasi yang kuat bagi para pembaharu Mesir untuk melakukan modernisasi pendidikan di Mesir yang dianggapnya stagnan. Lihat: http://id.wikipedia.org/wiki/Mesir
} 
itu beliau juga menentang keras dan menolak taqlid serta "ketidak benaran" dalam praktek keagamaan umat Islam. Secara istilah taqlid memiliki makna yaitu menerima ucapan atau keterangan seseorang walau orang tersebut tidak mengucapkan atau mencantukan dalilnya, seperti kita menerima keterangan dari imam Syafi'i tentang tertib dalam wudlu hukumnya wajib, walau Imam Syafii' tidak menyebutkan dalil tetapi kita mengamalkan keterangan tersebut, atau menurut pendapat lain; Taqlid adalah menerima ucapan pendapat atau keterangan seseorang (mujtahid atau ulama' tertentu) tanpa mengetahui darimana sumber keterangan tersebut diambil. ${ }^{3}$ Selanjutnya Ibn Taymiyah menyerukan umat Islam agar keluar dari kungkungan "sekat" mazhab-mazhab dan mulai memperbarui sistem berpikir serta menyelaraskan kembali hukum Islam yang sesuai dengan nilai-nilai yang terkandung dalam al-Kitab dan Sunnah Rasul (Ruju' ila al-Qur'an wa as-Sunnah asShohihah) ${ }^{4}$

\section{Wahabi: Potret Gerakan Pemurnian Tauhid}

Selain gerakan yang dipantik dari kairo ibukota Mesir, (dalam peta Mesir masuk pada wilayah benua Afrika), dalam rekam jejak sejarah perjalanan umat Islam; muncul juga satu gerakan dari Jazirah Arab, yang di dalamnya juga terdapat beberapa fase munculnya pemikiran kuat dengan tujuan perilaku "membersihkan" pelataran pola pikir kaum muslimin dari kemandegan dan kejumudan - yang hal tersebut - berbarengan adanya gerakan massif pemahaman literal tafsir terhadap ayat-ayat al-Qur'an yang berbarengan dengan perilaku keagamaan yang diusung oleh Muhammad bin Abdul Wahab (/1701M-1793M) yang dibackup olehkekuatan politik kerajaan, dengan Muhammad bin 'Saud al-Faishal sebagai penguasa saat itu, gerakan ini masyhur dikenal dengan sebutan

\footnotetext{
${ }^{3}$ Berangkat dari definisi Taqlid, ada dua unsur yang perlu diperhatikan, yaitu: 1). Menerima atau mengikuti suatu perkataan orang, 3). Perkataan tersebut tidak diketahui dasarnya apakah ada dalam al-Qur'an dan hadits. Lihat: Opcit. Hal. 132. Saiful Hadi. 2009. Ushul Figh, Yogjakarta, Sabda Media..h. 125.

${ }^{4}$ Opcit. Hal. 24-25. Lihat juga: Hilal, Iyad. 2005. Studi Tentang Ushul Fiqih, Bogor, Pustaka Thariqul Izzah. h. 132.
}

kaum salafi atau dengan nama "Wahabiyah atau Wahabi" yang dinisbatkan oleh pengikutnya pada pemilikide dan pelopor pertama gerakan pembaharuan ini. Namun dalam perkembangannya, Kaum Wahabi sendiri lebih memilih istilah al-Muwahhidun atau Ahl al-Tawhid untuk menamakan kelompok mereka. ${ }^{5}$ Dikisahkan, dalam sejarah perkembangan ajaran Wahabi ini, yakni pada tahun 1747 M, Muhammad bin Saud menyatakan secara terbuka penerimaannya terhadap berbagai pemikiran dan pandangan keagamaan Muhammad bin abdul wahab, hingga dalam waktu 10 tahun kekuasaannya berkembang, dan begitu pula dakwah Wahabi makin menguat dengan dukungan politik Ibnu Saud. Disebutkan antaraa Muhammad bin Saud dan Muhammad bin Abdul Wahab samasama diuntungkan, terjadilah simbiosis mutualisma antara paham keagamaan dan kekuatan politik sampai pada tahun 1757 M pengaruh Wahabi terhenti di (wilayah) Ihsa' ${ }^{6}$

Pandangan keagamaan Wahabi dalam masalah Tauhid, menurut mereka ada dua: tauhid rububiyah wa asma wa shifat dan tauhid rububiyyah dimana tauhid yang pertama bertujuan untuk mengenal dan menetapkan Allah sebagai Rabb dengan nama dan sifatsifatNya, dan tauhid yang kedua terkait dengan tuntutan dan tujuan (at-thalab wal qashad).

Fokus utama gerakan Wahabi adalah pemurnian tauhid dan akidah umat Islam. Mereka beranggapan umat Islam harus dibersihkan dari syirik baik syirik asghar (kecil)', syirik akbar (besar) dan syirik khaf ii (samar-samar). Di samping itu umat Islam dalam beribadah harus dimurnikan dari bid'ah baik bid'ah qawliyah i'tiqadiyah dan bid'ah fi al'ibadah.7 Kemunculan Wahabi sebagai satu gerakan keagamaan, pada mulanya berawal

${ }^{5} \mathrm{http}: / /$ paramadina.wordpress.com/2007/06/20/wahhabisme-sebagai-islam-puritan

${ }^{6}$ Wahid, Maghfur. 2010. Benarkah Hizbut Tahrir Muktazilah, Khawarij dan Wahabi?. Malang: Khilafah Institute. h. 15-16.

${ }^{7}$ Dalam kaca mata wahabi, permasalahan yang melanda ummat Islam terkini adalah masalah aqidah umat yang banyak mengandung kesesatan, prilaku syirik, bid'ah dan Khurafat. Ibid. h. 18-19. 
dari “keprihatinanyangmembuncah” tentang kondisi carut marutnya perkembangan sosial dan pemikiran di dunia Islam yang dalam pandangan seorang Abdul Wahab karena sarat dengan khurafat, kultus "pemujaan" indvidu, tahayul, pencemaran terhadap aqidah tauhidiyah dan ritual bid'ah yang mendekati syirik serta perilaku menyimpang lain yang "tidak dikenal dan terjadi" pada zaman Rasulullah SAW.

Lebih lanjut disebutkan ajaran Wahabi ini berkisar pada empat ajaran pokok: 1 . Kembali kepada ajaran-ajaran Islam yang asli, seperti yang ada dalam al-Qur'an dan hadis; 2. Kebutuhan untuk menyatukan iman dan perbuatan; 3. Pelarangan atas semua pandangan dan praktik yang tidak ortodoks. Hal ini menyebabkan, Muhammad bin Abdul Wahhab untuk sepanjang hidupnya memerangi praktik-praktik seperti penyembahan kepada para wali dan ziarah ke makam-makam dan tempat-tempat keramat untuk memperoleh berkah; 4. Pembentukan sebuah negara Islam yang secara khusus akan didasarkan kepada penerapan hukumhukumagama. SejauhkeluargaSa 'ud berhasil memperluas pengaruh dan wewenangnya di Arabia, sesuatu yang mendekati sebuah negara Islam sudah terbentuk. ${ }^{8}$

Melirik imbas paling kentara dari pemutlakan paradigma dua kutub bid'ah-sunnah ini telah menjadi semacam momentum tersendiri; sekaligus sebagai babak baru purifikasi total perilaku dan pemikiran keagamaan dalam dunia islam di antaranya adalah menolak (baca; menentang) segala aspek-aspek spiritualitas dari aksi ritual keagamaan sebagian golongan umat Islam yang mengadopsi kebijaksanaan lokal baik yang bersifat ritual sosial, lelakon dan perilaku budaya dan tradisi memaknai hari besar keagamaan dalam Islam atau perilaku lain yang bersifat kultural mu'amalah, yang notabene sudah men-darah daging dan mengakar tunjang bahkan sudah menyatu menjadi denyut jiwa kehidupan pada sebagian masyarakat tertentu. ${ }^{9}$

${ }^{8} \mathrm{http}: / /$ paramadina.wordpress.com/2007/06/20/wahhabisme-sebagai-islam-puritan

9 Dasar hukum persoalan bid'ah dalam agama ber-
Pada dekade akhir-akhir ini, juga terdapat segolongan dari kaum muslimin yang menerjemahkan nash-nash syar'i dari alQur'an dan hadits secara "apa adanya", melaksanakan hukum-hukum agama yang tersurat dalam nash, pendekatan yang literal terhadap fisik nash begitu kental, sebagian besar pada ayat-ayat penerapan hukum Islam (hukum syariah) dan ayat-ayat tentang jihad. Dalam hal ini, mereka bukan hanya memahami untuk kelompoknya sendiri saja, tapi berusaha menyebarkan dan menularkan pada orang lain dengan segala cara, termasuk mendefinisikan bahwa segala yang baru dalam agama itu bid'ah - maka wajib diberantas-, termasuk sistim baru kenegaraan, seperti demokrasi atau beberapa isu yang berkaitan dengan HAM, bahkan melekat pada kelompok ini prinsip setiap negara yang memerangi kaum muslimin pada hakekatnya penduduk negara itu wajib diperangi pula dimanapun mereka berada sehingga menimbulkan kasus seperti bom bali, pemboman hotel JW. Marriot, pemboman kedubes Australia dan Amerika dan teror bom di malam natal dan tahun baru, bahkan di malam pergantian tahun baru 2011 terjadi pengeboman di depan gereja Qadisiyin, Alexandria, Mesir, saat misa pergantian tahun yang menewaskan puluhan orang. ${ }^{10}$

Peristiwa demi peristiwa yang terjadi di atas, merupakan serangkaian tindakan teror atas nama agama, berdasar pada dalil nash yang dipahami secara "mentah". Pendekatan yang literal "hitam-putih" terhadap ayat, dengan menjadikan kepastian ganjaran surga - bagi pelaksana (baca: eksekutor) - sebagai alas tindakan ekstrim dan teror mereka.

dasar dari hadis yang diriwayatkan dari jalur Abdullah, bin Ja'far, al-Makhrami, Az-Zuhri, dan Ibrahim bin Saad bin Ibrahim bin Abdurrahman bin Auf dari al-Qasim bin Muhammad dari Aisyah ra. yang artinya: " siapa saja yang mengada-adakan sesuatu yang baru dalam urusan agama kami ini, yang bukan bagian darinya, maka tertolak. (HR Ahmad, Bukhori, Muslim, Abu Dawud, Ibn Majah). Lihat: bab . Hadits Pilihan, Abdurrahman, Yahya. 2010. “Semua yang Menyalahi Islam Tertolak". Jurnal al-Waie, No. 117 tahun X, 1-31 Mei 2010. Hal. 64. ${ }^{10}$ Misrawi, Zuhairi. Senin, 3 Januari 2011. Revitalisasi Islam "Rahmatan Lil Alamin". Kompas (Kolom 2-5). 
Pemahaman hukum-hukum agama dengan di sertai nafsu "menghabisi" siapapun yang cenderung berbeda dengan cara pandang ideologi keagamaan mereka, kini lambat laun berkembang dengan subur bak jamur di musim hujan dan ideologi kekerasan berlebel agama ini lebih dari hanya sekedar over truth claim beragama karena korelasi keyakinan mereka atas kebenaran nash berbanding lurus dengan sifat vandalistik sebagai efek dari keyakinan itu.

Adayang patut dicermati padabagian lain, fenomena yang berkembang dalam gerakan ini terbagi menjadi dua kelompok besar, dari kelompok yang pertama memilih jalan yang lebih ramah dan soft, dengan menghindari cara-cara kekerasan dan anarkisme akan tetapi lebih memilih upaya proaktif dengan menggarap dan melipatgandakan penyebaran isu-isu public serta lokal lewat penerbitan, demonstrasi serta unjuk rasa damai seperti tentang ketidakbecusan pemerintah dalam menangani maraknya kasus-kasus suap dan korupsi, mahalnya biaya pendidikan, kerusakan lingkungan, ketidakberpihakan APBN pada rakyat, lemahnya terhadap pelaksanaan undang-undang pornografi dan pornoaksi, dan liberalisasi ekonomi. Sembari memberikan tawaran sistem politik dan ekonomi yang bernuansa Islami, seperti sistem khilafah dan penerapan sistem Syariah secara murni di segala bidang kehidupan. ${ }^{11}$

Di fenomena lain, keberadaan budaya dan tradisi lokal seolah menahbiskan karakter, ciri serta tanda (arab; Qorinah) masyarakat; dimana budaya dan tradisi itu tumbuh berkembang dan sebagai simbol dimana manusia hidup di dalamnya, dus pada kenyataannya seringkali terdapat kebuntuan dialektika dan saling bergumul untuk saling mengalahkan antara keduanya (agama dan

11 Mereka mengistilahkan dengan dakwah siyasiyah (dakwah politis) dengan menerakan syariah Islam dan menghentikan sekularisme, selanjutnya -untuk menyelamatkan Indonesia dari keterpurukan lebih jauh- juga dengan mengkritisi sejumlah RUU APP, UU Migas, UU Sumber daya Air dan sebagainya yang bertentangan dengan Syariah. Lihat: Ismail Yusanto, 2010. "HTI Berjuang Untuk Indonesia Lebih Baik", Jurnal alWaie, No. 117 tahun X, 1-31 Mei 2010. Hal. 39-40. budaya) sehingga - sering ditemukan- ketegangan antara agama yang bersifat final, absolute, ilahiyyat dan keberadaannya sebagai simbol ketaatan manusia pada Tuhan dengan budaya, tradisi dan adat istiadat lokal yang muncul seiring dengan jejak kehidupan satu masyarakat.

Perspektif diatas, jelas mensyaratkan mesti terdapatnya bangunan interaksi positif dialektik agama-budaya dengan struktur yang tidak saling menohok tapi saling mengukuhkan eksistensi penerimaan, secara isi dan nilai yang bersifat agama dan sementara simbol bersifat budaya. Memperluas ruang sisi akulturatif ini dihajatkan guna meminimalisir dua wajah saling menentang Vis $a$ vis antara agama yang bersifat abadi (perennial), tak berubah, kebenarannya bersifat wahyu, serta final dan eksistensi tradisi budaya yang partikular, yang kemunculannya merupakan hasil cipta rasa, karsa dan karya manusia.

Melihat perilaku sebagian komunitas umat Islam dengan yang lain bahkan miris dirasa, dan dinyana, apalagi jika telah menjurus pada upaya pen- takfir-an satu dengan yang lain, seakan kita flashback ke belakang, pada pertarungan dahsyat historis perpolitikan setelah kemangkatan baginda Rasulullah SAW yang memunculkan golongan Syiah, Khawarij serta Ahlussunnah Wal Jamaah dan aliran mazhab pemikiran pasca ke-khalifahan kholafaurrasyidin yang merembet hingga dinasti Abbasiyah dengan keberadaan Baghdad sebagai trendsetter dan branding pemikiran pada masa itu, sebut saja peristiwa mihnah (inkuisisi) yang menebarkan "ngeri" ketika pressure penguasa yang memaksa golongan ulama' dan cendekia untuk mengakui bahwa al-Qur'an adalah makhluk.

\section{Islam Liberal: Dekonstruksi Teks, dan Desakralisasi Agama}

Sementara jika pointer kita arahkan pada dekade era kontemporer, terdapat golongan yang berupaya meliberalisasi pemahaman keagamaan dengan menempatkan Islam dalam konteks sejarah, yang sudah barang tentu "akan" menafikan sakralitas ajaran is- 
lam yang sudah baku, bersifat qot'iy dan tetap, dalam artian- massifikasi pendekatan liberal (liberal approach) terhadap ayat-ayat al-Qur'an dengan konsep yang extra fleksible bergantung pada realitas zaman, belum tentu kebenarannya.

Selain pendekatan baru liberalisasi makna ayat-ayat al-Qur'an dengan metode tafsir hermeneutika, kaum liberalis juga berusaha keras-dengan sedikit memaksamensinergikan maksud kandungan ayat-ayat al-Qur'an dengan kondisi kemanusiaan dan realitas asas-asas Hak Asasi Manusia (HAM) terkini, denganhujjah applikasi penerapannya yang bertumpu sama sekali pada aspek sosiologis, determinasi psikologis, Maslahah dan Maqosid syariah termasuk andaikata harus mendekonstruksi makna 'terdekat' dari ayat al-Qur'an - kalau - itu dibutuhkan demi dan atas nama "universalitas" kemanusiaan, jika tuntutan ayat "harus" bisa beradaptasi sesuai dengan konteks yang terjadi dalam dataran perilaku sosial-kemanusiaan, yang terpenting adalah bagaimana teks bisa terkoneksi dengan konteks. Kerangka sosiologis dan psikologis ini "memagari" bagaimana tindakan dan sikap keberagamaan seseorang dalam menilai sebuah peristiwa yang terjadi pada zamannya. Keberadaan Maslahat menjadi nyawa dan ruh utama dalam beragama dalam konteks kekinian, gerakan liberalisasi Islam ini, menyiratkan bahwa manusia adalah segalanya, seakan jika tanpa menghasilkan maslahat (bagi manusia) maka agama hanyalah fosil yang jauh dari memberi manfaat buat manusia dan kemanusiaan bahkan jika sekalipun itu adalah hukum Tuhan. Sebagaimana ungkapan salah satu tokoh liberal: "Syarat dasar memahami Islam yang tepat adalah dengan tetap mengingat, apa pun penafsiran yang kita bubuhkan atas agama itu, patokan utama yang harus menjadi batu uji adalah maslahat manusia itu sendiri." Diteruskan, "Jika Islam hendak diseret kepada suatu penafsiran yang justru berlawanan dengan maslahat manusia itu sendiri, atau malah menindas kemanusiaan itu, maka Islam yang semacam ini adalah agama fosil yang tak lagi berguna buat umat manusia". ${ }^{12}$ Menengok pada hal ini, pada dasarnya pemikiran-pemikiran gerakan Islam liberal dapat kita pilah, dan itu bertujuan untuk membongkar kemapanan beragama, bertradisi dan berpemahaman agama dari mainstream kaum muslimin. Secara gambling, cara-cara membongkar kemapanan itu dilakukan dengan tiga cara, yaitu: 1) Liberalisasi dalam bidang akidah Islamiyah, 2) Liberalisasi dalam bidang pemahaman al-Quran; dan, 3) Liberalisasi dalam bidang syariat dan akhlak disebutkan, adanya liberalisasi dalam bidang akidah yang diajarkan oleh kaum liberal, misalnya bahwa semua (kebenaran) agama sama, ${ }^{13}$ dan tentang pluralisme agama, hal ini bertentangan dengan akidah Islam Ahlussunnah wal jamaah. Sementara juga, dalam hal ini, kaum muslimin meyakini agama Islam sebagai agama yang haq dan paling benar, sebagaimana firman Allah SWT: yang artinya

"bahwa agama - di ridhoi- di sisi Allah adalah Islam"(QS. Ali Imran: 19),

dengan tidak menafikan hubungan yang baik dengan penganut agama lainnya yang memandang agama mereka juga benar menurut mereka. ${ }^{14}$

\footnotetext{
${ }^{12}$ Ungkapan Ulil Abshar Abdalla dalam tulisan "menyegarkan kembali pemahaman Islam", lihat http://jurnalparlemenonline.wordpress.com/2010/01/15/islam-2/

${ }^{13}$ “Dengan tanpa rasa sungkan dan kikuk, saya mengatakan, semua agama adalah tepat berada pada jalan seperti itu, jalan panjang menuju Yang Mahabenar. Semua agama, dengan demikian, adalah benar, dengan variasi, tingkat dan kadar kedalaman yang berbeda-beda dalam menghayati jalan religiusitas itu. Semua agama ada dalam satu keluarga besar yang sama: yaitu keluarga pencinta jalan menuju kebenaran yang tak pernah ada ujungnya". Tulisan Ulil Abshar Abdalla dalam "menyegarkan kembali pemahaman Islam", lihat http://jurnalparlemenonline.wordpress. com/2010/01/15/islam-2/

${ }^{14}$ Secara definisi aswaja adalah Kepercayaan tehadap Nabi Muhammad SAW dan sahabat-sahabatnya itu telah termaktub dalam al-Qur'an al-Karim dan sunnah Nabi secara terpencar-pencar, yang kemudian dikumpulkan dan dirumuskan dengan rapi oleh seorang ulama besar, yaitu Syeikh Abu al-Hasan al-Asy'ari (lahir di Basrah tahun $260 \mathrm{H}$ dan wafat di kota yang sama pada tahun $324 \mathrm{H}$ dalam usia 64 tahun). Dengan arti seperti di atas -cukup gamblang-, apa yang masuk dalam kelompok Ahlussunnah wal Jama'ah, pertamatama adalah para sahabat Nabi, para tabi'in dan tabiittabi'in, serta semua orang yang mengikuti jalan Nabi Muhammad SAW sampai hari kiamat kelak. Umam, Khotibul, et. All. 2009. Faham Ahlu Sunnah wal Jamaah
} 
Bila dilihat, ajaran pluralisme yang dimaksud oleh kaum liberal berlainan dengan pandangan konsep ukhuwah wathaniyah (persaudaraan sebangsa) yang dipegang kaum Nahdliyin yang dikenal dan menerapkan ajaran Islam rahmatan lil alamin, konsep moderat dalam keberagamaan yang mengokohkan solidaritas dengan saudara-saudara sebangsa. Disamping itu kaum liberal mengabaikan syariah sebagai hukum tuhan untuk dan demi kemaslahatan umat manusia, mengabaikan sikap tawadhu', akhlakul karimah dan ta'dim pada ulama' salaf, membatalkan otoritas mereka dan keagungan turats serta peradaban Islam. ${ }^{15}$

\section{Aspek Sosiologis dalam Kaidah Agama: Perspektif Islam Liberal}

Peran paradigma sosiologis yang begitu besar dalam frame pemikiran keagamaan kaum liberal, menyebabkan ketika ada persoalan keagamaan yang secara umum sudah maklum dan "baku" jawabannya dalam hukum agama menjadi mungkin untuk dilakukan eksplorasi lagi dengan menimbang aspek sosiologis dan sisi psikologis pada hukum (baca; jawaban) tersebut. Penetapan hukum atas satu persoalan, selama persoalan itu masih berkutat pada hubungan antar manusia (hablumminannas) pintu perdebatan dan pemberlakuan hukum lain selain yang sudah "diamalkan" oleh umat Islam, masih mungkin diterapkan ataupun ditinjau kembali.

Merumuskan ulang kaidah umum yang berkenaan dengan konsep maslahat 'ammah (kepentingan umum) misalnya, ketika kaidah tersebut dapat digunakan untuk menginterpretasi teks hukum secara berbeda, jadi ketika teks secara literal berbunyi "A" tapi kepentingan umum berkata lain maka tafsir yang dipakai bisa "B" yang berpihak pada kepentingan umum sekalipun harus berbeda dengan realitas teks. Berdasar fakta tersebut, semisal perbedaan interpretasi dengan gagasan tentang hubungan Islam dengan agama lain dengan meletakkan bahwa semua

Jakarta, PP.LAKPESDAM NU. Cet. Ke-1, h..7-8

${ }^{15} \mathrm{http}: / /$ www. Suara islam.com. news/ berita nasional/ forum kiai muda jatim/-jil-tak-punya-argumentasikuat/ agama itu benar meski tidak sama, memberikan ucapan selamat pada hari besar agama lain, aurat perempuan, anti poligami, dan nikah beda agama. ${ }^{16}$ Design Islam yang diperkenalkan dan ditawarkan oleh gerakan Islam Liberal adalah Islam yang substansial dalam memandang segala persoalan dengan barometer nilai kritis, universal dan mengedepankan pola pemecahan yang rasional. Teks mesti mengalami dekonstruksi, seperti pada hukum waris, pelaksanaan hudud (potong tangan) mesti menyesuaikan dengan kondisi perubahan waktu. ${ }^{17} \mathrm{Pe}-$ nyangkalan atas "hukum Tuhan" dan yang ada hanya prinsip umum universal, dan keharusan atas pelaksanaannya 'kudu' didekonstruksi dan hanya bertumpu pada tujuan umum syariah itu sendiri yang disebut maqashid shariah. ${ }^{18}$

\section{Epistemologi Islam Liberal: Pembacaan dan Penafsiran al-Qur'an}

Dalam pembacaan penafsiran, kita ambil contoh bagaimana Islam Liberal lebih mengutamakan bacaan yang baru yang lebih sesuai dengan semangat Islam Liberal sehingga ilmu yang sudah pakem dan paten dalam pembacaan al-Qur'an yaitu ulumul Qur'an bias dikesampingkan, bila tidak sesuai dengan konteks semangat zaman, hal ini sesuai dengan ungkapan koodinator Jaringan Islam Liberal, Ulil Abshar Abdalla: "Bahasa Arab itu semuanya konsonan. Ketika dihidupkan dengan memberikan harakat, bisa dibaca berbeda-beda. Misalnya ada ayat la yamassuhu illal mutathahhirun, yang artinya orang yang tidak berwudu tidak boleh menyentuh AlQuran. Tetapi, kalau dibaca la yamassuhu illal

\footnotetext{
${ }^{16} \mathrm{http} / / / \mathrm{www} . \quad$ Majalah.Tempo interaktif.com/id/ar$\operatorname{sip} / 2005 /$

${ }^{17 h t t p: / / w w w . ~ M a j a l a h . T e m p o ~ i n t e r a k t i f . c o m / i d / a r-~}$ $\operatorname{sip} / 2005 /$

${ }^{18}$ Ungkapan Ulil Abshar Abdalla dalam tulisan "menyegarkan kembali pemahaman Islam" "Menurut saya, tidak ada yang disebut "hukum Tuhan" dalam pengertian seperti dipahami kebanyakan orang Islam. Misalnya, hukum Tuhan tentang pencurian, jual beli, pernikahan, pemerintahan, dan sebagainya. Yang ada adalah prinsip-prinsip umum yang universal yang dalam tradisi pengkajian hukum Islam klasik disebut sebagai maqashidusy syari'ah atau tujuan umum syariat Islam. Lihat: http://jurnalparlemenonline.wordpress. com/2010/01/15/islam-2/
} 
muththahharun, artinya menjadi al-Quran itu tidak boleh disentuh kecuali oleh orangorang yang hatinya suci. Menurut saya, yang kedua ini jauh lebih tepat karena wudu secara fisik tidak penting. Banyak lagi ratusan bacaan dalam al-Quran seperti itu. Jadi, alQurannya sama, cuma cara membacanya kita pilih yang lebih sesuai". ${ }^{19}$

Ungkapan ini menegaskan bahwa Islam Liberal dalam memandang nash secara fisik lebih mengedepankan ruang dan waktu, karena kehadiran nash mesti mendahulukan kebutuhan manusia - dimana nash itu memang diperuntukkan keberadaannya bagi manusia- jadi apalah arti kehadiran nash di tengah-tengah manusia bila kehendaknya masih selalu di "langit", dan konteks manusia bersama ruang dan waktu selalu mengalami perubahan, tidak stagnan dan tetap. Dasar-dasar ini yang membungkus teori Mohammed Arkoun bahwa al-Qur'an adalah muntaj tsaqofi atau produk budaya, teori double movement Fazzlurrahman dan Nasr Hamid Abu Zayd yang intensif menggeluti kajian hermeneutik dalam tafsir klasik. ${ }^{20}$

Hal lainnya adalah, bagaimana Islam Liberal membuang organ-organ ornamental pada al-Qur'an yang dianggap sudah tidak lagi sesuai dengan zaman sekarang seperti kisah-kisah para nabi, kaum dan bangsa yang dihancurkan Allah SWT seperti kaum Ad dan Tsamud, juga lainnya secara fisik tidak lagi dibutuhkan hanya di ambil pesan moralnya.

Senada dengan yang di atas, sebelum melangkah terlalu jauh, ada baiknya kita sedikit menyinggung apa yang acap kali didengungkan oleh gerakan Islam Liberal ketika menggagas diterapkannya metode hermeneutika dalam penafsiran al-Qu'an, sebagaimana kita maklum, hermeneutika adalah salah satu tema gerakan pemikiran Islam yang dijadikan isu sentral oleh Islam

\footnotetext{
${ }^{19} \mathrm{http} / / /$ www. Majalah.Tempo interaktif.com/id/ar$\operatorname{sip} / 2005 /$

${ }^{20}$ Apa yang dilakukan oleh fazlurrahman, arkoun, dan abu zayd, adalah contoh bagimana mengolah al-qur'an dengan hermeneutika. Fahruddin Faiz. 2005. Hermeneutika Al-Qur'an Tema-Tema Kontroversial. Yogjakarta: El-SaQ press. Hal. 15.
}

Liberal. Hingga untuk semakin 'lebih' akrab dikenal, gerakan Islam Liberal mengadakan serangkaian kegiatan yang bersifat rutin, sistimatis dan skematis, mulai dengan lingkar diskusi kecil, mengundang tokoh-tokoh yang bersimpati dan memiliki kemiripan afiliasi dengan gerakan ini dan menyiarkannya lewat media radio-radio, sampai dengan mengadakan seminar dan workshop di gedung dan hotel.

Islam Liberal menganggap bacaan dan upaya para mufassirin klasik terhadap teks (nash) masih lebih mengedepankan pemahaman teksyang berasal darireader (pembaca/ dirinya), sehingga terkesan ada penggagahan (baca; penguasaan atas kebenaran teks dari sang absolute yang "tak terbatas" oleh yang reader yang "terbatas") mengapa dalam membaca sebuah teks (nash), dibutuhkan hermeneutika? gerakan Islam Liberal lebih berupaya menangkap maksud dari teks tersebut dengan "menghindarikesewenang-wenangan penafsiran" - yang dalam kacamata mereka- seringkali terjadi dan dilakukan oleh individu atau sekelompok orang yang membatasi keinginan Tuhan (the will of divine) atau keinginan terdalam maksud teks dengan memberikan batasan final serta merupakan hasil akhir terhadap kehendak teks yang tidak dapat dibantah dan diganggu gugat. ${ }^{21}$

Dalam perspektif pendekatan hermeneutik, variable pemahaman manusia itu sedikitnya melibatkan tiga unsur yaitu unsur author (pengarang), unsur teks dan unsur reader (pembaca) yang masing-masing unsur dalam proses pemahaman memiliki peran dan fungsinya sendiri, sehingga mengunggulkan peran salah satu unsur atau mengabaikan peran salah satu unsur lainnya hanya akan membawa "kesewenang-wenangan dalam memahami". ${ }^{22}$

Dalam bahasa lain, bangunan Hermeneutika berkisar pada tiga elemen pokok yakni: teks, interpreter dan audien yang lazim dikenal dengan triadic structure. Dalam garis besarnya, konsentrasi para pengkaji her-

\footnotetext{
${ }^{21}$ Ibid. kata pengantar M. Amin Abdullah, hal. xx.

${ }^{22} \mathrm{Ibid}$, kata pengantar, M. Amin Abdullah. hal. xviiixix.
} 
meneutika adalah berkisar seputar segitiga teks, pengarang dan pembaca (hermeneut). Adapun diantara tiga sisi adalah berpusat pada teks sebab ialah produk yang ditelorkan oleh pengarang dan itulah tema yang menjadi konsentrasi pembaca. ${ }^{23}$

Selanjutnya berangkat dari sini, aplikasi tafsir dengan terapan metode hermeneutika diharapkan -adanya- eksistensi al-Qur'an lebih mampu menjawab persoalan kemanusiaan terkini, karena munculnya semangat relasi kuat dialektika antara teks-konteks-kontekstualisasi, sehingga seorang mufassir dapat dengan leluasa menangkap spirit makna teks dan dapat melakukan produksi makna baru sesuai dengan realitas ruang dan waktu,- acuannya- dimungkinkan terciptanya al-Qur'an yang sholihun likulli zaman wal makan.

Hermeneutika $^{24}$ dalam menilai tafsir dengan memandangnya bahwa tidak ada tafsiryang tetap, dalam perspektif bahwa semua tafsir adalah produk akal manusia yang sifatnya relatif, yang parsial- kontekstual, temporal dan personal dan "bisa saja keliru". Berangkat dari paham relativisme ini maka tidak ada lagi satu kebenaran yang diterima semua pihak, semua manusia bisa salah. Dengan demikian menurut hermeneutika ini tidak ada tafsir yang qath'i, tidak ada yang pasti kebenarannya, semuanya relatif, semuanya dzanni. ${ }^{25}$

Selanjutnya, baiknya senyampang kita lihat sebagaimana yang dilakukan oleh Mohammed Arkoun dengan proyek dekonstruksi al-Qur'an dengan varian pembacaan linguistik, semantis dan antropologis, dalam pengertian menghindari makna teologis ketika membaca al-Qur'an, dan Nasr Hamid

\footnotetext{
${ }^{23}$ Adian Husaini dan Abdurrahman al-Baghdadi. 2007. "Hermeneutika dan Tafsir al-Qur'an". Jakarta, Gema Insani Prees. h. 31.

${ }^{24}$ Hermeneutika pada dasarnya merupakan satu penafiran yang berangkat dari analisa bahasa dan melangkah pada analisa konteks lalu menarikk makna yang didapat ke dalam ruang dan waktu saat pemahaman dan penafsiran tersebut dilakukan. h. 15.

${ }^{25}$ Paham relativisme tafsir ini sangat berbahaya, diantaranya: menghilangkan keyakinan akan kebenaran dan finalitas Islam, dan menempatkan Islam sebagai agama sejarah yang selalu berubah mengikuti zaman. Ibid, h. 19-20.
}

Abu Zayd dengan metode analisis linguistik, yang meletakkan al-Qur'an tak lebih dari teks yang diproduksi realitas, alias "muntaj tsaqofi atau produk budaya", ${ }^{26}$ yang menganggap bahwa sumber keilahian al-Qur'an bertentangan dengan analisis ilmiah obyektif karena telah mengorbankan dimensi manusia untuk kemaslahatan Allah, ${ }^{27}$ serta metode materialis historis oleh Hassan Hanafi yang secara garis besar melakukan pembacaan dan pemahaman dengan menghubungkan wahyu ke realitas (wahyu selalu datang untuk pembenaran terhadap realitas yang sedang hidup), tidak membutuhkan semua dalil naqli dan mendorong sisi humanis bukan teologis. ${ }^{28}$

\section{Nash Syar'i dalam Perspektif Pemahaman dan Aksi Islam Fundamentalis}

Kedudukan nash syar'i atau sebut saja alQur'an dan sunnah nabawiyyah di kalangan kaum fundamentalis adalah amat signifikan. Sepenggal kalimat di atas bagaimana cara pandang dan aksi gerakan mereka terhadap nash.

Nash bagi kaum fundamentalis adalah pesan yang "hidup", apa yang tersurat haruslah dilaksanakan dan dilakukan dalam ranah kehidupan sebagaimana disebutkan:

"Orang-orang yang telah Kami berikan Al Kitab kepadanya, mereka membacanya dengan bacaan yangsebenarnya[tidakmerubahdanmentakwilkan sesuka hatinya, mereka itu beriman kepadanya. dan barangsiapa yang ingkar kepadanya, Maka mereka Itulah orang-orang yang rugi" (QS. AlBaqarah: 121)

dan penerapannya dalam kehidupan sebagaimana dalam salah satu kandungan al-Qur'an:

"Ini adalah sebuah kitab yang kami turunkan kepadamu penuh dengan berkah supaya mereka memperhatikan ayat-ayat-Nya dan supaya mendapat pelajaran orang-orang yang mempunyai fikiran. "(QS. Shad: 29).

\footnotetext{
${ }^{26}$ disebutkan"...karena bahasa adalah produk budaya, maka al-Qur'an yang berbahasa arab juga produk budaya arab" lihat.Ibid. h. 33.

${ }^{27}$ Fahmi Salim. 2010. Kritik Terhadap Studi Al-Qur'an Kaum Liberal. Jakarta: Perspektif. h. 230.

${ }^{28}$ Ibid. h. 231-234.
} 
Visi keislaman yang jelas dari cara pandang kaum fundamentalis dan militan Islam yang "menolak demokrasi liberal" ala barat dan memiliki sikap pandangan, bahwa dalam wilayah politik tidak ada garis tegas yang memisahkan antara Islam dan politik, juga hubungan agama dan Negara. Dalam semangat memperjuangkan agama (baca: Islam) adalah sudah semestinya bila perjuangan politik Islam yang kaffah mestilah diwujudkan dengan berdirinya satu bentuk negara Islam yang berdasar syariah. Agama tak dapat dipisahkan dari negara; dan pada dasarnya agama mengatur seluruh aspek kehidupan dan hubungan antar manusia melalui negara yang terwujud dalam konstitusi, legislasi dan berbagai undangundang yang mengatur kehidupan bernegara dan bermasyarakat.

Dari sini, sebagaimana organisasi HTI (Hizb tahrir Indonesia) yang memperjuangkan bentuk pemerintahan Islam dengan sistem khilafah. Dalam tulisannya, Irfan Ali menyatakan: "Secara ideologis, HTI merupakan organisasi Partai Politik Islam yang berdiri pada tahun 1953 di Timur Tengah, di Negara Yordania. Saat ini HTI sudah memiliki cabang di hampir 30 negara termasuk Indonesia. Namun di Indonesia HTI mewujud sebagai organisasi masa (ormas) yang berjuang di luar sistem politik negara untuk menegakkan syari'at islamiyah dibawah naungan daulah khilafah, suatu sistem pemerintahan yang dipimpin seorang khalifah. $^{29}$ Taqiyuddin an-Nabhani sendiri menyatakan tentang definisi khilafah yaitu: "Khilafah adalah kepemimpinan kaum Muslim di seluruh dunia untuk menegakkan syariat Islam, mengemban dakwah Islam ke seluruh penjuru dunia. Khilafah itu sama dengan imamah". ${ }^{30}$ SemangatmendirikannegaraIslaminibergaung karena dianggap dengan kekuatan politik ini Islam dapat berkembang, disamping bahwa semestinya mereka menjalankan perintah Allah SWT, bahwa dalam beragama mesti utuh dan penuh totalitas, dalam segala hal,

29 http://politik.kompasiana.com/2010/04/01/fenomena-hti-kajian-akademis/

30 Opcit. h. 23. sejurus dengan firman Allah SWT dalam alQur'an :

"Wahai orang-orang yang beriman, masuklah kamu ke dalam Islam secara keseluruhan dan janganlah kalian mengikuti langkah-langkah syaitan. Sesungguhnya syaitan itu musuh nyata bagi kalian" (QS. al-Baqarah: 108).

Memaknai kata-kata sepenuhnya (kaffah) dalam al-Qur'an, bahwa Islam mewajibkan bahwa setiap kehidupan diatur oleh agama Islam, ${ }^{31}$ dan adanya institusi negara Islam dibutuhkan keberadaannya untuk menjamin keberlangsungan dijalankannya sistem hukum yang Islami yang sesuai dengan tuntunan Syariah, yang memaklumkan satu agenda pemerintahan yang bukan berbentuk sistem kerajaan, republik ataupun parlementer bahkan khilafah bukan wujud dari satu pemerintahan yang berbentuk dengan sistem demokrasi, teokrasi maupun autokrasi ataupun federasi, uni, kekaisaran dan commonwealth tapi khilafah adalah Negara kesatuan. Menurut HT (Hizb Tahrir), agar segala sesuatunya berjalan secara ideal, maka khilafah harus dibangun di atas empat pilar sebagimana berikut: 1 . Kedaulatan di tangan Syariat, 2. Kekuasaan di tangan umat, 3 . Hanya ada satu khalifah yang di baiat, 4 . Hanya khalifah yang diberi kewenangan mengadopsi hukum untuk dijadikannperundang-undangan. ${ }^{32}$

Berdasarkan paradigma krusial ini, maka seluruhhukum-hukumIslam tanpa terkecuali harus diterapkan kepada manusia, sebagai konsekuensi adanya iman atau aqidah Islamiyah. Konsep aqidah menjadi peran vital utama yang membranding seluruh aktivitas dakwah HT dalam mewujudkan dasar utama ideal Negara, perlembagaan (konstitusi) dan undang-undang yang berdasarkan syariah Islam, serta setidaknya, aqidah Islamiyah ini mencakup dua hal, yaitu aqidah aqliyah (aqidah yang menjadi dasar pemikiran) dan aqidah siyasiyah (aqidah yang menjadi dasar politik) yang melahirkan aturan untuk me31 Rahmat Kurnia, Muhammad.. Tak ada pemisahan agama dan Negara dalam Islam. Jurnal al-Waie no.116 Tahun X, 1-30 April, 2010. h. 57. 32 Opcit. Hal. 23-24. 
mecahkan problematika manusia dalam politik, ekonomi, sosial, budaya dan lainlain. ${ }^{33}$ Sehingga bukan hanya memberikan porsi ruang (sphere) yang cukup bagi agama tetapi juga ikut mewarnai dan mendasari terhadap segala kebijakan dalam pengaturan Negara adalah niscaya. Seterusnya, Keberadaan HT dalam mem-floorkan ide dan dakwah Islamiyahnya berdasar pada tiga tahapan thariqah/marhalah; antara lain : 1 . Marhalah tsaqif: tahapan pembinaan dan pengkaderan, dalamrangka mencipta kerangka tubuh partai. 2. Marhalah tafa'ul ma'ah ummah: tahapan berinteraksi dengan umat, dalam rangka agar umat turut meikul dakwah Isla dan menjadika Islam sebagi permasalahan utama. 3. Marhalah istilam alhukm (tahapan pengambil alihan kekuasaan) yang dilaksanakan untuk menerapkan Islam secara menyeluruh dan mengemban risalah Islam keseluruh dunia. ${ }^{34}$ Sudah pada Tentunya hal ini dalam perspektif semangat, bahwa Aqidah Islamiyah yang telah "memerintahkan" penerapan agama secara utuh menyeluruh. Berkaitan dengan masalah ini, terdapatnya konsep al-Islamu din minhu addawlah (Islam adalah agama termasuk di dalamnya Negara), menyitir pendapat Ibnu Taymiyah, yang menegaskan: Jika kekuasaan terpisah dari agama atau agama terpisah dari kekuasaan niscaya keadaan manusia akan rusak," nyatalah jika agama itu menyatu dengan negara. Diteruskan, ketika Islam diterapkan oleh Negara maka kesucian agama terjaga dan kebebasan untuk beragama pun terjaga, sebagai wujud dari pengamalan firman Allah SWT , yang artinya:

"tidak ada paksaan dalam agama (QS. AlBaqarah: 256). ${ }^{35}$

33 Diantara thariqah (methodologi) dakwah HT berdasar pada firman Allah SWT yang artinya:" sesungguhnya bagi kamu pada diri Rasulullah SAW terdapat Uswatun hasanah" (QS. al-Ahzab: 21), dan firman Allah SWT yang artinya: katakanlah (Muhammad) jika kalian (benar-benar) mencintai Allah, ikutlah aku, niscaya Allah mengampuni dosa-dosa kalian (QS. Ali Imran: 31). Dan al-Qur'an surat al-Hasyr: 7. lihat: http://www.slideshare.net/cucur/ m12-mengenal-hizbut-tahrir

34 http://www.slideshare.net/cucur/m12-mengenalhizbut-tahrir

35 Rahmat Kurnia, Muhammad.. Tak ada pemisahan agama dan Negara dalam Islam. Jurnal al-Waie no.116 Tahun X, 1-30 April, 2010. h. 59.
Cukup jelas bahwa, realisasi (dalam memahami) perintah dari nash adalah pemahaman yang "hitam- putih" yakni dibutuhkan ketegasan memilih; bagaimana aqidah Islamiyah dapat dijalankan dengan sempurna, bagaimana kehidupan yang Islami dapat diterapkan sebenar-benarnya. Pendekatan literal terhadap teks inilah yang membuat banyak faksi, mazhab pemikiran keagamaan yang militan serta tumbuhnya berbagai "lasykar" dalam Islam, yang tentunya menggunakan berbagai macam pendekatan ideologi dari yang menghindari kekerasan yang bersifat anarkis hingga yang menggunakan term radikal dengan militansi, serta visi-misi seirama; mendirikan Negara berdasar syariah Islam.

\section{Muslim Moderat: Membumikan Paham Islam Rahmatan Lil Alamin}

Di ranah pilihan lain, muncul sikap moderasi, dengan meminjam pemaknaan "ideologi moderat" atau "ideologi tengah" ketika memberi arti identitas keberagamaan dengan rasa kepasrahan dan semangat untuk selalu menggapai keselamatan.

Istilah moderat memiliki arti "sikap pertengahan", dengan sikap menghindari atau mengurangi ekstrimitas (misalnya: dalam

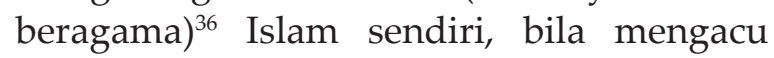
pada keberadaannya sebagai agama yang dihadirkan sebagai agama keselamatan, agama yang mengusung sikap pertengahan antara sikap berlebihan (ghuluw) dan sikap ceroboh dan acuh tak acuh terhadap agama serta dalam beragama.

Representasi teologis dari sikap moderasi ini minimal tercermin dari lima sikap, yaitu pertama; sikap moderat dalam masalah sifat-sifat Allah antara meniadakan sifat-sifat Allah (ta'thil) dan menyerupakan sifatsifat Allah, kedua; disamping itu juga moderat dalam masalah pengkafiran tidak mudah mengkafirkan atau memurtadkan sebagaimana yang dilakukan oleh kaum khawarij, juga tidak menafikan-samasekalipengkafiran seperti kaum Murji'ah, ketiga;

36 Bull, Victoria. 2010. Oxford Leaners Pocked Diary. Oxford: Oxford university Press. h. 283. 
sikap moderat dalam masalah takdir dengan menghindari sikap kemandirian penuh perbuatan manusia yang jauh dari campur tangan tuhan seperti kaum Qadariyah atau manusia sama sekali tidak memiliki kehendak sebagaimana golongan Jabariah, keempat; moderat dalam sikap terhadap pemerintah yaitu sikap antara memberontak (bughot) dan acuh tak acuh dalam menasehati pemerintah dalam undang-undang dan kebijakan publik (control of government rule and public policy), lima; moderat dalam menyikapi karomatul awliya' (karomah atau derajat kemuliaan para wali) dengan barokahnya dengan membenarkannya namun tidak juga berlebihan sampai memuja kuburankuburannya.

Sikap moderat dalam pemahaman keilmuan keagamaan adalah sikap jalan tengah yang dengan tegas mengelaborasi pemikiran-pemikiran keagamaan yang berpijak teguh pada al-Qur'an dan hadits dengan menetapkan Ijma' (konsesus) para ulama Salafush Shalih dan para Mujtahidin, menghormati, mengkaji dan membedah turats sebagai khazanah kekayaan peradaban keilmuan Islam serta konsisten dalam meneguhkan adanya Ijtihad terhadap persoalan-persoalan manusia dan kemanusiaan yang terkini dan terbarukan, selalu menjalankan sunnah Rasulullah SAW dan menjauhi segala yang dilarang, melaksanakan amar ma'ruf nahi mungkar sebagaimana firman Allah swt: "apa yang diberikan rasul padamu terimalah ia dan apa yang dilarangnya bagimu tinggalkanlah; dan bertakwalah kepada Allah. Sesungguhnya Allah sangat keras hukuman-Nya" (QS. al- Hasyr: 7), juga sebagaimana firman Allah swt: "kamu adalah umat yang terbaik yang dilahirkan untuk manusia, menyeru kepada yang ma'ruf dan mencegah dari yang mungkar dan beriman kepada Allah' (QS. Ali 'Imron: 110).

Sikap moderat dengan jalan tengahnya menjadikan kehadiran Islam sebagai agama rahmatan lil alamin, jauh dari sikap ekstrim (tathorruf) dan membabi buta dalam beragama (menjalani agama) juga menjauhi sikap beragama yang "longgar" yang terasing dan menjaga jarak dari tuntunan nash, serta sebagaimana dapat kita pahami, bahwa akar kata "Islam" berasal dari kata "aslama, yuslimu, islaman" dimana "etimologi "salam" yang memiliki arti damai dan menyelamatkan. Implikasi dari pemaknaan tersebut memunculkan keniscayaan bagi setiap muslim dalam mengimplementasikan nilai-nilai ajaran Islam tidak lain adalah untuk menciptakan kedamaian dan keselamatan kepada seluruh alam tanpa terkecuali. Senada, dengan hal ini, adalah ungkapan Dr. KH. Saied Aqil Siraj, dalam tulisannya "menyikapi Kegarangan Puritanisme" bahwa otentisitas keislaman apakah harus kearab-araban apakah Isalam otentik mesti "garang' terhadap semua yang bukan dari islam, tradisi lokal dan modernitas? ${ }^{38}$

Implementasi nilai-nilai keislaman yang rahmatan lil alamin adalah bagaimana Islam hadir mencipta harmoni dalam sikap membangun toleransi positif bagi semua kelompok agama dan aliran kepercayaan, sebagaimana semangat dalam Q.S. al-Kafirun ayat 1-6, dimana kita sebagai umat islam tahu bahwa di sekeliling kita ada keyakinan dan kepercayaan atau iman lain yang kita dituntut untuk memahami dan menghormati dengan pemahaman dan penghormatan yang wajar sebagaimana mereka lakukan pada kita.

Ada beberapa aspek konstruktif yang dijadikan asas yaitu nilai-nilai persaudaraan yang kita kenal dengan sikap ukhuwah. Dalam moderasi yang dibangun berdasar sikap ukhuwah ini, sebagaimana yang dirumuskan oleh KH. Akhmad Siddiq (rais am PBNU), yaitu tiga konsep model persaudaraan yaitu al-ukhuwah al-Islamiyah (persaudaraan keislaman), al-ukhuwah wathoniyah (persaudaraan kebangsaan), al-ukhuwah al-basyariy-

\footnotetext{
37 Yunus, Mahmud. Kamus Arab -Indonesia, Jakarta. Karya Agung. h. 177.

38 Membincang gerakan puritanisme islam pada umumnya gerakan yang menganggap dirinya laebih benar dari lawannya, bahkan, Said Aqiel Siraj mengutip pendapat khaled aboe el-Fadoel tentang Islam puritan ini, dengan menyatakan: mereka adalah kelompok atau gerakan yang sengaja memisahlan diri dari mainstream umat. Mereka cenderung ekslusif, egoistis dan sering kritis terhadap ulama' yang mapan., Said Aqiel Siraj, "Menyikapi kegarangan Puritanisme", Jawa Pos, Selasa, 5 April 2011, (kolom 3).
} 
190 | de Jure, Jurnal Syariah dan Hukum, Volume 2 Nomor 2, Desember 2010, hlm. 178-194

yah (persaudaraan kemanusiaan). ${ }^{39}$

\section{Tiga Model Ukhuwah: Nafas Moderasi Dan Harmoni Dalam Beragama, Bernegara Dan Berperikemanusiaan.}

Model ukhuwah yang dikembangkan seperti ini pada dasarnya adalah barometer dari rasa kecintaan dan persaudaraan sebagai sesama pemeluk agama Islam, sebagai sesama warga yang tinggal dan bertumpah darah di sebuah wilayah yang disebut Indonesia dan sebagai sesama makhluk penghuni dunia yang diciptakan oleh Allah swt.

\section{Al-ukhuwah al-Islamiyah}

Persaudaraan keislaman, yaitu adanya kemanunggalan dan kesamaan dalam iman sebagai seorang Muslim yang menyembah Allah swt. Sifat dari ukhuwah Islamiyyah lebih menekankan bahwa sesama muslim pada hakekatnya adalah saudara, sebagai mana hadits Rasulullah saw "bahwa muslim itu bersaudara, ibarat anggota badan, bila satu merasa disakiti maka anggota yang lain akan merasakannya"diletakkannya al-ukhuwah alIslamiyah, di urutan pertama dari konsep moderasi ini, karena persaudaraan sebagai sesama umat Islam merupakan dasar bangunan moderasi ini.

Sebagai sesama pemeluk Islam tentunya diharapkan memiliki ikatan emosional yang jauh lebih kuat untuk saling mendukung dan membantu dalam mencapai tujuan duniawi dan ukhrawi secara berimbang. Selayaknya ikatan persaudaraan, upaya diatas diterapkan tanpa menghilangkan hak dan kewajiban masing-masing dengan aturan-aturan yang telah menjadi kesepakatan bersama, dalam artian dengan segala potensi yang dianugerahkan Tuhan pada umat Islam.

Menjaga ukhuwah sesama mukminin dalam Islam, adalah dengan perasaan bahwa seolah mereka itu seperti satu tubuh, bila satu anggota sakit maka anggota tubuh lainnya akan juga merasakan kesakitan itu juga, demikian ini sebagaimana tergambar dari firman Allah swt:

39 Zuhairi Misrawi. Senin. 3 Januari 2011. Revitalisasi Islam "Rahmatan Lil Alamin". Kompas. (Kolom 2-5) "dan tolong menolonglah kamu dalam mengerjakan kebajikan dan taqwa dan jangan tolong menolong dalam berbuat dosa dan pelanggaran (QS. Al-Ma'idah: 2),

sebagaimana hadits Nabi Muhammad SAW:

"perumpamaan kaum mukminin dalam cintamencintai, sayang menyayangi, dan bahu membahu seperti satu tubuh, jika salah astu anggota tubuhnya sakit, maka seluruh anggota tubuhnya yang lain ikut merasakan sakit juga, dengan tidak bisa tdur dan demam. (HR. Bukhori-Muslim),

Selanjutnya, semangat moderasi ini akan menjadi lebih kokoh dengan memungkinkannya umat islam membangun harmoni dengan kebudayaan tradisi agama lain, sejurus dengan itu, mengadopsi diktum "mempertahankan tradisi masa lalu yang baik sembari mempertahankan -mengambilnafas tradisi kekinian yang lebih baik" (almuhafadzah ala al-qadim al-shalih wa al-akhdzu bi al- jadid al-ashlah) adalah langkah ideal yang dapat diterapkan untuk membangun peradaban dan keadaban publik dalam konteks keindonesiaan, moderasi dalam bertindak dan berprilaku dan berpemahaman agama ini, sebagaimana firman Allah SWT, yang artinya:'

Demikianlah kami menjadikan kamu umat yang moderat (jalan tengah) (QS. Al-Baqarah: 143).

\section{Al- Ukhuwah al-Wathoniyah}

Dalam membangun semangat persaudaraan sebangsa, umat islam mesti memiliki sikap toleransi kepada sesama anak bangsa. Pada garis besarnya, keberadaan umat islam yang menempati wilayah negara kesatuan Republik Indonesia yang terbentang dari sabang hingga merauke diharapkan memberi konstribusi positif produktif bagi perkembangan persaudaraan dan persatuan. "Persahabatan" umat islam dengan pemeluk agama lain dalam aspek muamalat misalnya atau bagaimana umat islam Indonesia bisa menerima Pancasila sebagai asas tunggal dalam bernegara maupun bermasyarakat adalah kiprah nyata dalam kerelaan untuk membangun bersama elemen bangsa lainnya. Bila merunut selama sejarah perjuangan se- 
masa era penjajahan dan perang kemerdekaan tak terhitung konstribusi serta pengorbanan nyata baik nyawa, darah dan airmata umat islam sejak perlawanan zaman penjajahan potugis sejak 1511-1605, masa Belanda selama 3.5 abad, Inggris hingga era Jepang, bahkan dalam masa pembentukan pemerintahan di awal-awal kemerdekaan bahkan ketika menyusun pancasila sebagai dasar negara.

Diceritakan oleh kiai Salahuddin Wahid dalam kilas sejarah, saat para kiai dan ulama' dari organisasi Nahdlatul Ulama' (NU) mengadakan rapat di Surabaya berkaitan dengan adanya informasi shahih bahwa pada akhir September 1945 tentara Belanda (NICA) mendompleng tentara sekutu untuk kembali merebut dan menancapkan kembali kekuasaannya di Indonesia, yang pada akhirnya para ulama yang dimotori oleh KH. Hasyim Asy'ari pada tanggal 22 oktober 1945 mengeluarkan naskah perjuangan umat Islam yaitu resolusi jihad ${ }^{40}$ sebagai bentuk perlawanan atas segala hal yang berbau penindasan dan penjajahan. Dimana isi lengkap dari naskah resolusi jihad ${ }^{41}$ ini adalah mendorong pemuda islam ${ }^{40}$ Naskah pidato perlawanan dari hadrotus syaikh KH. Hasyim Asy'ari itu disampaikan dengan bahasa arab dengan maksud tagar tidak terendus oleh belanda: diantar isi pidato itu adalah: "Apakah ada dan kita orang yang suka ketinggalan, tidak turut berjuang pada waktu-waktu ini, dan kemudian ia mengalami keadaan sebagaimana yang disebutkan Allah ketika memberi sifat kepada kaum munafik yang tidak suka ikut berjuang bersama Rasulullah... Demikianlah, maka sesungguhnya pendirian umat adalah bulat untuk mempertahankan kemerdekaan dan membela kedaulatannya dengan segala kekuatan dan kesanggupan yang ada pada mereka, tidak akan surut seujung rambut pun.Barangsiapa memihak kepada kaum penjajah dan condong kepada mereka, maka berarti memecah kebulatan umat dan mengacau barisannya....Maka barangsiapa yang memecah pendirian umat yang sudah bulat, pancunglah leher mereka dengan pedang siapa pun orangnya itu..." lihat:http://www.lakpesdam.or.id/publikasi/290/memahamikembali-maknaresolusi-jihad

${ }^{41}$ NADLATOEL OELAMA “R E S 0 B L U S 1" MOEKTAMAR NAHDLATOEL 'OELAMA' ke-XVI jadi diadakan di POERWOKERTO moelai malam hari Rebo 23 hingga malam Sabtoe Rb. 'oetsani 1365, bertepatan dengan 26 hingga 29 Maret 1946.

Mendengar: Keterangan2 tentang soesana genting jang melipoeti Indonesia sekarang, disebabkan datangja kembali kaoem pendjadjah, dengan dibantoe oleh kakitanganja jang menjeloendoep ke dalam masjarakat Indonesia:

Mengingat:a. bahwa Indonesia adalah negeri Islam, b. bahwa Oemmat Islam dimasa laloe telah tjoekoep menderita kedjahatan dan kezholiman kaoem pendj- yang tinggal dalam radius $94 \mathrm{KM}$ dari kota Surabaya untuk ikut membantu BKR (Badan keamanan Rakyat) dalam perang melawan tentara Belanda dan Inggris, teriakan bung tomo dengan pekikan... Allahu Akbar! Membakar semangat para pemuda dan masyarakat Surabaya dan daerah sekitarnya untuk berperang dengan semangat menang atau mati syahid. dengan semangat keberagamaan yang dipadu dengan rasa kecintaan pada tanah air, umat islam telah menorehkan tinta emas di sepanjang kelokan sejarah Indonesia.

Dari titik inilah sebenarnya -untuk kesekian kali- peran pesantren, kiai dan para ulama' yang di back up dengan semangat ukhuwah wathoniyah dan pernyataan hubbul wathon minal iman yang bermakna cinta tanah air adalah sebagian dari iman menggugah umat islam untuk berjuang bahu membahu menyelamatkan bangsa dan negara dari tangan penjajah, sehingga dengan peran dan keikut sertaan ulama' dalam perjuangan menjadikan 10 nopember dikenal sebagai hari pahlawan, hari pengorbanan segenap elemen bangsa. Rasanya tidak berlebihan, jika semangat persaudaraan sebangsa ini diterapkan dalam konteks modern dalam waktu kekinian dimana saatnya keikhlasan adjah;

Menimbang: a. bahwa mereka (Kaoem Pendjajah) telah mendjalankan kekedjaman, kedjahatan dan kezholiman dibeberpa daerah daripada Indonesi.b. bahwa mereka telah mendjalankan mobilisasi (Pengerahan tenaga peperangan) oemoem, goena memperkosa kedaoelatan Repoeblik Indonesia;

Berpendapatan: Bahwa oentoek menolak bahaja pendjadjahan itoe tidak moengkin dengan djalan pembitjaraan

sadja;1. Berperang menolak dan melawan pendjadjah itoe Fardloe 'ain (yang harus dikerdjakan oleh tiap2 orang Islam, laki2, perempoean, anak2, bersendjata atau tidak (bagi orang jang berada dalam djarak lingkaran $94 \mathrm{Km}$. Dan tempat masoek kedoedoekan moesoeh). 2. Bagi orang2 jadi berada diluar djarak lingkaran tadi, kewadjiban itu fordloe kifayah (yang tjoekoep, kalau dikerdjakan sebagian sadja). 3. Apa bisa kekoeatan dalam No. I beloem dapat mengalahkan moesoeh, maka orang2 jang berada diloar djarak lingkaran $94 \mathrm{Km}$. Wadjib berperang djoega membantoe No. 1,sehingga moesoeh kalah. 4. Kaki tangan moesoeh adalah pemetjah kegoelatan teqad dan kehendak ra'jat, dan haroes dibinasakan menoeroet hoekoem Islam sabda Chadits, riwajat Moeslim. Resoeloesi mi disampaikan kepada:1. P.J.M. Presiden Repoeblik Indonesia dengan perantaraan Delegasi Moe'tamar. 2. Panglimatertinggi T.R.l. 3. M.T. Hizboellah 4. M.T. Sabilillah 5. Ra'jat Oemoem .lihat: lihat:http://www.lakpesdam.or.id/publikasi/290/memahami-kembali-maknaresolusi-jihad 
dan ketulusan berjuang yang tumbuh dari nilai-nilai relegiusitas dapat mengisi ruang waktu pasca revolusi fisik perang kemerdekaan yang sudah terjadi lebih dari setengah abad yang lalu.

Aura positif keIslaman menjadipendorong kejujuran (honesty) dalam menjalankan amanah masyarakat dari segenap segmen baik politik, hukum, seni-budaya, dan pertahanan serta ketahanan bangsa. Bahkan beranjak lebih jauh, produktivitas persaudaraan sebangsa ini, menjadi penyanggah bangunan peradaban dan elan vital spirit bangsa menjadi bangsa teladan yang baldatun thayyibatn wa rabbun ghafur.

\section{Al- ukhuwah al-basyariah}

Tipologi ukhuwah yang ketiga adalah persaudaraan kemanusiaan, umat islam melihat manusia lain sebagai saudara sesama makhluk yang diciptakan Allah SWT, yang secara hukum mereka berhak mendapat perlindungan baik nyawa dan harta bendanya. Berangkat dari satu pemahaman dan perilaku keberagamaan bahwa umat islam datang dengan damai dan membawa rasa aman baik terhadap individu maupun komunitas sosial tidak terkecuali alam dan lingkungan sekitar, bukankah Rasulullah SAW sendiri menyatakan: "barang siapa yang beriman pada Allah swt dan hari akhir hendaklah ia memuliakan dan menghormati tetangganya" atau dalam satu riwayat disebutkan, Rasulullah SAW pernah mengatakan: "celakalah orang yang tetangganya tidak merasa aman dari mulut dan tangannya". Terminologi "tetangga" dalam Islam adalah bilangan 40 rumah atau kepala keluarga dari empat pejuru mata angin ke arah barat, timur, utara dan selatan, yang mana hak penghormatan kita pada mereka dengan tidak menyakiti mereka dan selalu mengulurkan kebaikan pada mereka, tanpa mempertimbangkan aspek apapun kecuali bahwa tetangga kita adalah manusia yang harus dihormati keberadaannya. hal ini sebagaimana perintah Rasulullah SAW dalam hadits yang diriwayatkan oleh Imam Bukhori
Muslim dan Ibnu Majah. ${ }^{42}$ Pengedepanan aspek kemanusiaan ini juga menyentuh sikap tolong menolong dan saling meringankan beban kala bencana atau kesusahan menimpa. Aspek ini pada dasarnya meletakkan solidaritaskepada sesama sebagai tulang punggung utama, dengan ketulusan membantu dan meringankan beban siapapun 'yang membutuhkan tanpa melihat status, strata, suku agama, ras dan adat. Penghargaan kita sebagai pribadi amatlah menentukan terhadap bagaimana wajah agama Islam di hadapan manusia sekalian dan dunia.

Ukhuwah basyariah memberdayakan dan mencipta pribadi unggul serta menempatkan segala urusan kemanusiaan dengan penuh penghargaan sebagai sesama ciptaan Tuhan, bukankah persaudaraan yang tulus akan menciptakan perdamaian, sebagaimana hubungan sosial membutuhkan saling pemahaman dan keterbukaan.

Mengaca dari konsep Islam moderat yang mengusung teologi jalan tengah dengan berupaya membumikan wajah Islam yang rahmatan lil alamin setidaknya ada lima hal yang harus dilakukan; pertama adalah senantiasa menciptakan dialog interaktif dinamis antara teks (nash) dan konteks sehingga diharapkan akan tercapai hasil pemikiran yang konstruktif-produktif dalam membangun situasi dan kondisi sosial yang Islami, kedua; mengembangkan sikap perilaku keberagamaan (baca: keislaman) yang mendorong kearah terwujudnya maslahatul 'ammah (kemaslahatan publik) yang lebih berpihak pada isu-isu krusial yang berkembang di tengah masyarakat semisal

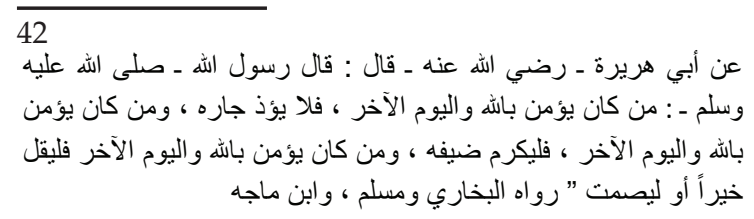

Yang artinya: Dari Abu Hurairah r.a. berkata, Rasulullah saw. bersabda, "Barangsiapa yang beriman kepada Allah dan hari akhir, maka jangan menyakiti tetangganya. Dan barangsiapa yang beriman kepada Allah dan hari akhir, maka hendaklah menghormati tamunya. Dan barangsiapa beriman kepada Allah dan hari akhir, hendaklah berkata baik atau diam." (Bukhari, Muslim, dan Ibnu Majah). Lihat http://keluargasakinahh.blogspot.com/2009/01/5-hadits-tentangtetangga.html 
kemiskinan, terorisme, terjaminnya menjalankan agama dan kepercayaan tanpa unsur penodaan, perdagangan anak dan perempuan (traficking), pendidikan murah, buruh, tenaga kerja migran, pelayanan kesehatan, peningkatan taraf hidup, stabilitas harga, dan sebagainya, harus mendapat porsi pemikiran kaum musimin, sehingga masalah-masalah kebangsaan, keummatan, dan kemanusiaan menjadi agenda utama pemikiran Islam, ketiga; mengembangkan sikap toleransi positif saling menghargai berdasarkan kesadaran tatanan realitas kemajemukan, sebagaimana semangat utama kemanusiaan dan keagamaan dalam bergaul serta dalam suasana kebersamaan, keempat; menguatkan rangka konstruksi penghargaan dan penghormatan pada perempuan yang berkeadilan, menjauhi penindasan dan kekerasan baik fisik maupun mental, kelima; menjunjung Hak Asasi Manusia dalam kebersamaan, mengutamakan dialog dan mendahulukan hikmah dan mauidlotul hasanah dalam menyelesaikan problematika kemanusiaan serta menjauhi segala bentuk kekerasan atas nama aliran dan agama.

\section{Kesimpulan}

Dari berbagai macam mazhab yang ada dalam Islam mulai mazhab pelaksanaan dalam ibadah dan muamalah hingga pilihan pemikirandenganmenampilkanperformance masing-masing dari segi argumentasi yang diback up dalil naqli maupun aqli, manhaj, bangunan ide hingga epistemologi yang mendasari gerakan-gerakan itu, sebut saja Islam liberal dengan dekonstruksi konsep

\section{DAFTAR PUSTAKA}

Bull, Victoria. 2010. Oxford Leaners Pocked Diary. Oxford: Oxford university Press.

Faiz, Fahruddin. 2005. Hermeneutika Al-Qur'an Tema-Tema Kontroversial. Yogjakarta: ElSaQ press.

Koto, Alaiddin. 2006. Ilmu fiqih dan Ushul Figh. Jakarta: PT. Raja Grafindo Persada.

Umam, Khotibul, et. All. 2009. Faham Ahlu Sunnah wal Jamaah Jakarta, wahyu, gerakan wahabi dengan pemurnian tauhid, salafi, dan eksistensi Islam Moderat yang mengusung konsep Islam rahmatan lil alamin, Islam dengan design seperti ini adalah Islam yang tersampaikan dengan wajah ramah, humaniter, dan toleran. Islam yang memilih jalan tengah dengan menghindari sikap berlebihan dalam beragama (ghuluw) dan tidak peduli, sikap yang membangun paradigma hubungan sosial dengan asas dialog antara teks (nash) teologis dengan konteks, menghormati dan sekuat mungkin membumikan pesan dan nilai wahyu dan teks ulama' yang melintas dalam peradaban panjang umat Islam (turats), sembari mengembangkan sikap keberagamaan positif konstruktif dan dinamis serta berimbang demi menciptakan masyarakat ideal dengan cita-cita utama kesejahteraan, masyarakat Islami namun sarat toleransi, memberi pada minoritas dan kaum mayoritas ruang publik yang cukup dan berkeadilan, dengan semangat ukhuwah islamiyah, ukhuwah watoniyah, ukhuwah basyariah, yang menjadi pemantapan persaudaraan keummatan, persaudaraan kebangsaan dan penghargaan pada kemanusiaan. Tak pelak lagi, membumikan wajah keberagamaan ini sebagai pilihan strategis di masa kekinian, ketika Islam sebagai agama bukan hanya dituntut bisa bertahan, tapi dakwahnya berkembang meluas dengan cara yang elegant, bukankah al-Qur'an memberi patokan untuk menyampaikan Islam dengan hikmah dan mauidlotul hasanah dan Allah SWT menyatakan bahwa diutusnya Nabi Muhammad SAW sebagai rahmatan lil alamin. Wallahu a'lam.

PP.LAKPESDAM NU. Cet. Ke-1.

Salim, Fahmi. 2010. Kritik Terhadap Studi Al-Qur'an Kaum Liberal. Jakarta: Perspektif.

Hilal, Iyad. 2005. Studi Tentang Ushul Fiqih, Terjemah oleh Abu Faiz. Bogor: Pustaka Thariqul Izzah.

Hadi, Saiful. 2009. Ushul Figh, Yogjakarta, Sabda Media. 
194 | de Jure, Jurnal Syariah dan Hukum, Volume 2 Nomor 2, Desember 2010, hlm. 178-194

Ismail, Muhammad Muhammad. 1958. Refreshing Pemikiran Islam. Terjemahan oleh A.Haidar. 2004. Bangil: Al-Izzah.

Wahid, Maghfur. 2010. Benarkah Hizbut Tahrir Muktazilah, Khawarij dan Wahabi?. Malang: Khilafah Institute.

Yunus, Mahmud. Kamus Arab -Indonesia, Jakarta. Karya Agung.

Yusanto , Ismail, 2010. "HTI Berjuang Untuk Indonesia Lebih Baik", Jurnal, al-Waie, No. 117 tahun X, 1-31 Mei 2010.

Rahmat Kurnia, Muhammad. Tak ada pemisahan agama dan Negara dalam Islam. Jurnal al-Waie no.116 Tahun X, 1-30 April, 2010.

Wahid, Salahuddin. 20 Januari 2011. Tokoh Agama Dan Politik. Jawa Pos: 4 (Kolom 2-4).

Misrawi, Zuhairi. 3 Januari 2011. Revitalisasi Islam "Rahmatan Lil Alamin". Kompas. 6 (Kolom 2-5).

Aqiel Siraj, Said. Selasa, 5 April 2011, "Menyikapi kegarangan Puritanisme", selasa, Jawa Pos, (kolom 3).

http://www.lakpesdam.or.id/publikasi/290/ memahami-kembali-maknaresolusi-jihad/ di akses 25/05/2011.

http://www.slideshare.net/cucur/m12mengenal-hizbut-tahrir/ di akses 25/05/2011.

http://politik.kompasiana.com/2010/04/01/ fenomena-hti-kajian-akademis/di akses 24/05/2011

http://jurnalparlemenonline.wordpress. com/2010/01/15/islam-2/ di akses 23/05/ 2011.

http://id.wikipedia.org/wiki/Mesir/ diakses 23 Mei 2011.

http://keluargasakinahh.blogspot.com/hadits-tentang-tetangga.html/ diakses 24/05/ 2011

http://paramadina.wordpress.com/ wahhabisme-sebagai-islam-puritan/ di akses 25/05/2011

http://www. Suara islam.com. news/ berita nasional/ forum kiai muda jatim/-jiltak-punya-argumentasi-kuat/ diakses 22/ 01/ 2011.

http://www. Majalah.Tempo interaktif.com/ id/arsip/2005/ diakses 10/01/2011. 